Journal of Qualitative Criminal Justice \& Criminology • 2020 | Volume 9, Issue 1

\title{
Public Opinion of the Police in 1930s America: A Qualitative Historiographical Study
} Willard M. Oliver ${ }^{1}$

${ }^{1}$ Sam Houston State University

Published on: Nov 17, 2020

DOI: $10.21428 / 88 \mathrm{de} 04 \mathrm{a} 1.190647 \mathrm{bb}$

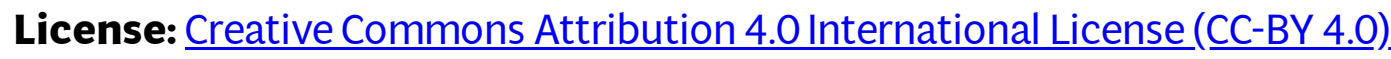




\section{ABSTRACT}

Public opinion polls largely developed post-WWII and questions about the police did not appear until the late 1960s. Since then, over 100+ studies have assessed the modern-day public opinion of the police, but none have looked to public opinion from an earlier time period. This study uses a qualitative historiographical approach for assessing public opinion of the police in the 1930s by drawing on the primary source of a letter exchange between two of that eras greatest pulp writers: Robert E. Howard and H.P. Lovecraft. Findings suggest similarities between the 1930s and present day public opinion of the police.

\section{Introduction}

Although public opinion polls began at least as early as 1824 when The Harrisburg Pennsylvanian surveyed locals about who was most likely to win the presidential election that year and The Literary Digest successfully predicted the presidential victories of Harding (1920), Coolidge (1924), Hoover (1928) and Roosevelt (1932), scientific polling did not come about until 1936 (Hillygus, 2011; T. Smith, 1990). These early scientific polls, mostly by Gallup and Roper, were problematic due to poor sampling techniques, but by the 1960s, they had become a staple of American life (Converse, 2009; Hogan, 2009; Mayer, 1993; Moon, 1999; Page \& Shapiro, 1992). There is, however, a lack of knowledge of public opinion before scientific polling came into its own, which is what led Berinski (2006) to make the statement that "our understanding of the dynamics of mass opinion and behavior prior to the 1950s has ... been more limited" (p. 499).

Public opinion polls about the police did not appear consistently until the early 1970s, after crime had risen to unprecedented levels, and the police were clashing with protestors and anti-war demonstrators (Flanagan \& Longmire, 1996). At that time, Gallup began asking Americans to rate the honesty and ethical standards of police, while the General Social Survey, through the National Opinion Research Center, asked citizens about police use of force.

Criminal justice was becoming its own academic program in colleges and universities across the United States at about this same time, so academic research on the public's opinion of the police soon saw widespread publication. It was Decker's $(1981,1985)$ seminal research in the early 1980s that launched the ever-expanding research in this area, as evidenced by Brown and Benedict's (2002) meta-study that assessed over 100 
Journal of Qualitative Criminal Justice \& Criminology • 2020 | Volume Public Opinion of the Police in 1930s America: A Qualitative Historiographical

articles on public attitudes toward the police that included a time period from the early studies through those in 2001.

In the wake of the 1960s police-community clashes, public perceptions of the police polls developed into an area of policing research that has allowed closer observations of public perceptions of the police in the post-Ferguson era. Yet what is still not known today is how Americans perceived the police in the past, especially during another era in which the public clashed with the police such as in the 1920s and 1930s, an era that was marked by both police corruption and brutality (Friedman, 1993; Walker, 1998). No public opinion data are available from this time period, but what has recently become available is a letter exchange (1930-1936) in which two pulp fiction authorsH. P. Lovecraft and Robert E. Howard-discussed and debated numerous topics, including the police and, more specifically, police corruption, police brutality, and the third degree (Joshi, Schultz, \& Burke, 2017).

The purpose of this study is to take a historiographical approach to understanding what public opinion of the police was like in the 1930s through a qualitative analysis of these recently available letters.

\section{Literature review}

In his seminal research, Decker (1981) analyzed the effects that both individual (e.g., sex, race) and contextual (e.g., crime rates, neighborhood) variables have on public attitudes toward the police. He concluded that age, contact with the police, neighborhood, and race all have significant impacts on public attitudes toward the police. In 2002, Brown and Benedict reassessed Decker's findings by analyzing over 100 journal articles related to perceptions of the police. From their review of these studies, they concluded, "only four variables (age, contact with police, neighborhood, and race) have consistently proven to affect attitudes toward the police" (p. 543). The researchers did note that there was at least one variable considered to be a confounding variable because it can influence the other variables in question; this confounding variable is "the effect that political affiliation and personal ideology (conservative or liberal) have on attitude toward the police" (Brown \& Benedict, 2002, p. 565). The research has generally found that those who identify as Republicans and those who report having conservative views are more likely to have a favorable opinion of the police, while Democrats and liberals tend to have a less favorable view of the police (Albrecht \& Green, 1977; Benson, 1981; Gabbidon \& Higgins, 2008; Hindelang, 1974; Huang \& Vaughn, 1996; Zamble \& Annesley, 1987). Because these two variables are often compared to each other and to such things as education, they can result in 
Journal of Qualitative Criminal Justice \& Criminology • 2020 | Volume Public Opinion of the Police in 1930s America: A Qualitative Historiographical

contradictory variables in a study (Brown \& Benedict, 2002). They can also confound certain people's views of the police, for instance, if a Black conservative exhibits more favorable views of the police than other Blacks because of their ideology.

Brown and Benedict (2002) also discussed individuals' perceptions of police according to their age group. Their research pertaining to age demonstrated that younger people had less favorable views of the police than did older people, and their age categories were large. Those individuals under 40 years of age tended to hold less favorable views of the police, while those over 60 years of age held more favorable views.

The research on contact with the police has generally found that positive contact improves public perception of the police, while negative contact has the opposite effect (Bridenball \& Jesilow, 2008; Ekins, 2016; Miller \& Davis, 2008; D. Smith, Graham, \& Adams, 1991; Worrall, 1999). Studies that assessed which factors had the greater effect presented mixed findings; some stated that positive contact has a greater effect (Cheurprakobkit, 2000; Huang \& Vaughn, 1996; Scaglion \& Condon, 1980) while others pointed to negative contact shaping public opinion the most (Dean, 1980; Jacob, 1971). Other researchers found that witnessing or knowing of police corruption could also create negative perceptions (Dean, 1980; P. Smith \& Hawkins, 1973; Thomas \& Hyman, 1977). Still further, some studies suggested that citizen-initiated contact with police promoted positive perceptions (Cheurprakobkit, 2000), that when crime victims were satisfied with an officer's handling of their case, this improved their perceptions (Chandek, 1999; Reisig \& Chandek, 2001; Stephens \& Sinden, 2000), and when someone was arrested, their perception of the police diminished (P. Smith \& Hawkins, 1973).

Research related to a person's neighborhood has generally been shown to influence public perceptions of the police (Dunham \& Alpert, 1988; Gabbidon \& Higgins, 2008; Miller \& Davis, 2008; Reisig \& Parks, 2000; Sampson \& Jeglum-Bartusch, 1998; Skogan, 1978; Weitzer, 1999). However, as Brown and Benedict (2002) summarized, "There is no consensus about why attitudes toward the police vary by neighborhood" (p. 556). The studies on the composition of the neighborhood by race and ethnicity have shown mixed data (Apple \& O’Brien, 1983; Weitzer, 1999), as have the results on the differences between rural and urban neighborhoods. Some researchers reported that small-town and rural citizens had a more negative view of the police (Janeksela et al., 1976; Zamble \& Annesley, 1987), while others demonstrated that urbanites were more likely to view the police less favorably (Albrecht \& Green, 1977; Clark \& Wenninger, 1964). Several scholars noted that rural residents had more favorable 
Journal of Qualitative Criminal Justice \& Criminology • 2020 | Volume Public Opinion of the Police in 1930s America: A Qualitative Historiographical

views of police use of force and crime prevention than did urban residents (Huang \& Vaughn, 1996; Worrall, 1999).

There is an extensive body of research on the effects of race on public opinion of the police (Brown \& Benedict, 2002). Research has consistently demonstrated that Blacks have less favorable opinions of the police than do either Whites or Hispanics (Gabbidon \& Higgins, 2008; Miller \& Davis, 2008; Thomas \& Hyman, 1977; Weitzer \& Tuch, 1999; Worrall, 1999).

Finally, the one confounding variable found by Brown and Benedict (2002) consists of political affiliation and ideology. The research has generally found that those who identify as Republicans, and those who report having conservative views, are more likely to have a favorable opinion of the police, while Democrats and liberals tend to have a less favorable view of the police (Albrecht \& Green 1977; Benson, 1981; Gabbidon \& Higgins, 2009; Hindelang, 1974; Huang \& Vaughn, 1996; Zamble \& Annesley, 1987). Because these two variables are often related to each other and to such things as education, they can often be confounding variables in a study (Brown \& Benedict, 2002). They can also confound certain people's views of the police. For instance, a black conservative may exhibit more favorable views of the police than other blacks because of their ideology.

For the purposes of this study, two of these variables, race and age, were not explored. Lovecraft was 16 years older than Howard, but it should be noted that at the beginning of their correspondence, he was 40 years old and Howard was 24; there was not enough of a difference between their ages for the age span to matter. Lovecraft and Howard were also both White, so race cannot be explored as an influencing factor. What can be explored were their personal contacts with the police, their neighborhoods (Lovecraft was from a city, whereas Howard was from a rural town), and politics and ideology (Lovecraft was a conservative Republican, and Howard was a liberal Democrat).

\section{Methods}

This study used a qualitative method of historiography to assess public opinion of the police in the 1930s. According to Berg (2009), "Historiography ... is a method for discovering, from records and accounts, what happened during some past period" (p. 296). Although the use of historical writings as data has a long history in academia, its application in the social sciences did not come about until the late $20^{\text {th }}$ century (Iggers, 1997). Classical historiography focuses heavily on political and economic 
Journal of Qualitative Criminal Justice \& Criminology • 2020 | Volume Public Opinion of the Police in 1930s America: A Qualitative Historiographical

history (Jayapalan, 2008), while modern historiographers have used these methods to study social and cultural history (Bentley, 1999; Momigliano, 1990). According to Berg (2009), studying social and cultural history through historical research allows the ability to "recapture complex nuances, the people, meanings, events, and even ideas of the past that have influenced and shaped the present" (p. 297; see also Leedy \& Ormond, 2005; McDowell, 2002). Using the preserved correspondence between H. P. Lovecraft and Robert E. Howard allowed this researcher to recapture public opinion of the police from a time period that, like today, experienced difficulties with policecommunity relations.

\section{Robert E. Howard}

Robert E. Howard was born on January 22, 1906, in Peaster, Texas, to a father who was a small-town physician (Finn, 2013). The family moved often as Howard was growing up until they finally settled in Cross Plains, Texas, in the north-central part of the state. From an early age, Howard was an avid reader, and he began writing fiction at the age of nine. Although he was not fond of the restrictions of school, he graduated from Brownwood High School in May of 1923 (Cross Plains only went through $10^{\text {th }}$ grade) and then embarked on a career in writing for the pulps. His first publication was in Weird Tales magazine in 1925, which became the primary outlet for his publications. Howard developed a number of series characters, including Solomon Kane and King Kull, and his most popular character was Conan. By virtue of these characters, he created a new genre in literature, one that came to be known as sword and sorcery. Howard also wrote in many other genres, including boxing tales, adventures, westerns, and comedic tall tales. The writer never married and was largely responsible for taking care of his tubercular mother, because his father, a small-town doctor, was always on call. When his mother was on her deathbed, on June 11, 1936, Howard used a pistol to commit suicide. He was 30 years old.

\section{H. P. Lovecraft}

Howard Philips Lovecraft was born in Providence, Rhode Island on August 20, 1890, and spent all of his life there, except for a brief time when he lived in New York City (Joshi, 2013). When Lovecraft was eight, his mother and father died within a few months of each other, so he was sent to live with an aunt who raised him. Lovecraft was a sickly introverted child, but he loved to read and write. He began writing supernatural horror stories at a young age that developed from traditional ghost stories into tales of cosmic horror. He is best known for developing the Cthulhu Mythos and encouraged many of his correspondents to write about those characters. He was 
Journal of Qualitative Criminal Justice \& Criminology • 2020 | Volume Public Opinion of the Police in 1930s America: A Qualitative Historiographical

also a prolific letter writer in adulthood; it is estimated that he wrote well over 100,000 letters, most of which were lengthy letters often numbering 20 pages. Many were over 50 pages in length. He began publishing his works in Weird Tales magazine, and he, along with Howard and Clark Ashton Smith, were considered the three dominant writers of that magazine. Lovecraft developed cancer and died on March 15, 1937, at the age of 46 .

\section{The Lovecraft-Howard correspondence}

Lovecraft wrote a short story titled "The Rats in the Wall" in the summer of 1923 and included a sentence in Gaelic from a previously published story, "The Sin-Eater" (1895), by Fiona Macleod (Joshi, 2010). The story was published in the March 1924 issue of Weird Tales magazine and, because of its popularity, was reprinted in the same magazine in the June 1930 issue. At the end of the story, the English character regresses back in time and begins speaking earlier languages, which is why Lovecraft used the Gaelic sentence. However, as he wrote his friend, Frank Belknap Long, "The only objection to the phase is that it's Gaelic instead of Cymric as the south-of-England locale demands. But as with anthropology_details don't count. Nobody will ever stop to note the difference" (Joshi, Schultz, \& Burke, 2017, p. 7). One person, however, did note the difference, and that was Robert E. Howard from Cross Plains, Texas. Howard wrote to the editor of Weird Tales magazine, Farnsworth Wright, and asked him if by using Gaelic instead of Cymric, Lovecraft was basing his story on some new theory in linguistics. Wright eventually put Howard in contact with Lovecraft and their letter exchange began in the summer of 1930 (Finn, 2013).

\section{Data}

The data for this study comes from the 2017, second edition, softcover publication of $A$ Means to Freedom: The Letters of H.P. Lovecraft and Robert E. Howard, published by Hippocampus Press. It is a two-volume set-Volume 1 includes the years 1930 to 1932 (pp. 1-511), and Volume 2 covers from 1933 to Howard's death in June of 1936 (pp. 512-1006). The letters were edited by H. P. Lovecraft and Robert E. Howard scholars, S. T. Joshi, David E. Schultz, and Rusty Burke, from previous collections of Howard's (Roehm, 2007) and Lovecraft's collected letters (e.g., Joshi \& Schultz, 2008; Schultz \& Joshi, 2017). There are 129 identified letters in their voluminous correspondence, which is estimated to be over 400,000 words (Joshi, 2010). Approximately 5\% of the letters are non-extant and are annotated as such in the collection. Although this signifies that some data are missing from their correspondence, they often reminded each other of what was said in previous letters, and because there was little mentioned 
Journal of Qualitative Criminal Justice \& Criminology • 2020 | Volume Public Opinion of the Police in 1930s America: A Qualitative Historiographical

that does not appear in the extant letters, it is believed the problem of missing data is minimized, although still prevalent.

The topics covered in the letters ranged from the personal to commentary on the other's writings and regional discussions, but the primary topic is their debate regarding barbarism versus civilization. Many of the topics that stemmed from this debate included discussions of crime, violence, disorder, and the police. Focusing on the discussion relevant to the police, this researcher identified portions of the letters related to the police by using the index, by conducting a casual read of the letters, and concluding with two close reads specifically searching for the term. By separating out the police-related material, a total of 34 pages out of the entire 1,006 pages of correspondence in the book were located. This amounted to 11,368 of the estimated 400,000 words and comprised $.028 \%$ of their total correspondence.

These 34 pages were treated as qualitative data and were analyzed using a grounded theory approach (Charmaz, 2008, 2014; Charmaz \& Belgrave, 2002; Glaser \& Strauss, 1967). A three-step method was applied that used open coding, axial coding, and selective coding (Strauss \& Corbin, 1998). The data were read and sorted based on the various topics discussed by Lovecraft and Howard (open coding) and were then resorted into common themes (axial coding). Finally, the major themes were developed (selective coding) that focused on their personal experiences with the police, the differences between their neighborhood environments (urban vs. rural), police corruption, police brutality, use of the third degree in questioning suspects, romanticism toward law enforcement, and, to some degree, their policy solutions for fixing the problems they identified with American policing.

\section{Findings}

\section{First mention of the police}

Robert E. Howard and H. P. Lovecraft began corresponding in June of 1930, but it was not until two years later that the police were first mentioned in their letters. In a July 13, 1932 letter, Howard described the Santa Claus Bank Robbery that had occurred in the nearby town of Cisco, Texas in 1927 (See Greene, 1999). During the robbery, several robbers, two police officers, and a half-dozen citizens were killed or wounded. The purpose of Howard's recounting was to highlight the story of legendary lawman, Texas Ranger Manuel "Lone Wolf” Gonzaullas. Lovecraft countered by writing back that violence was not commonplace where he lived, "In New England, a crime of violence by an American is so rare as always to command a front-page newspaper 
spread" (p. 334). He then explained to Howard how the police would respond to a gunman in a bar:

Some one would tell a policeman, who in turn would telephone to the station from a corner box and bring four to six uniformed men in a fast patrol car. They would rush the maniac, probably using their guns, and quickly get him into the patrol and in a cell. Then he would be examined for sanity, tried, and placed either in an asylum or jail. (p. 334)

This was Lovecraft's first comment to Howard that focused on the police and not on violence. Howard's reply to the letter was also the first mention he made of the police other than telling Lovecraft his Texas anecdote. On August 9, 1932, Howard wrote the following:

I note that some indignation is being expressed over the country in regard to the detestable police practice of grilling prisoners. Its about time. I think police harshness is mainly because the people have become so cowed by the heel of the law, that they do not resent or resist any kind of atrocity inflicted on them by men wearing tin badges. (p. 349)

For the next three-and-a-half years, their letters would continue to return to the topic of the police.

\section{Personal police contact}

Over the period of their correspondence, Howard and Lovecraft shared the types of personal contact they had with the police on previous occasions. Howard, who lived primarily in extremely small towns throughout his life, explained to Lovecraft, "I was nearly fourteen years old before I lived-for any length of time-in a community which supported a law officer" (p. 385), thus qualifying that any experience he had with the police did not come until his teenage years. He later restated this to Lovecraft when he wrote, "I have lived for years in communities in which there wasn't an officer of the law within forty miles" (p. 948) and suggested that even when there was a police officer that Howard was aware of, they were not close by.

Howard then explained his personal contacts with the police by first qualifying how, "I've always been a quiet, law-abiding citizen, to the best of my ability. Yet I, in common with most of my acquaintances, have occasionally broken laws" (p. 384). Howard also distinguished his life as being different from Lovecraft's, particularly 
regarding the people they associated with. Howard was quite blunt in challenging Lovecraft on this issue when he wrote the following:

[I]f you'll pardon me for saying so, I have an idea that between the two of us, my first-hand experience with criminal types is the wider. I've been personally acquainted with gunmen, crooked gamblers, bootleggers, dope-fiends and peddlers, bad-check experts, thieves, rustlers, smugglers and what not. (p. 830)

Despite these occasional violations of the law and associations with criminal types, he later told Lovecraft,

I've never had but one brush with the police, but I must say that did not increase my respect for the system. I was about eighteen or nineteen ... and the lad driving ... got confused, made a mistake and drove across a stop-light. ... The cop who stopped us seemed to consider our blunder a personal insult. He lashed himself into a perfect rage. ... We were glad to be told the rules and regulations. ... But we did resent being treated like gangsters and thugs. (p. 505)

Thus, Howard's contact with the police was limited and, as he stated in another letter quite succinctly, "I’ve never been arrested” (p. 796).

Howard was right concerning Lovecraft's personal experience with the police, for he had much less to say about his personal experience with the police. As Lovecraft explained to Howard, “I've never been arrested. Nobody I know has ever been arrested. And certainly the people I happen to know are no exceptional group in the community" (p. 796). Although Lovecraft lived in Providence, Rhode Island, where the police department in 1930 numbered 539 officers (Milkovits, 2014), he did not mention much contact with them, only recalling,

I have seen some cases of impatience and apparent overbearingness by traffic policemen, but have always had an inclination to pardon most of these in view of the constant irritation and nervous strain under which the guardians of heavy and complex traffic must labour. That kind of work and responsibility must wear down the nerves even worse than the more seemingly arduous duties of the men on beats. (p. 515)

\section{Urban versus rural}

The two pulp fiction authors lived in vastly different neighborhoods. Robert E. Howard lived in a rural setting, while H.P. Lovecraft lived in an urban setting. Howard was 
from Cross Plains, Texas, a small-town located in the central part of the state, which had a population of 1,507 in 1930. Lovecraft was from Providence, Rhode Island, a large city in the northeast portion of the state, which boasted a population of 252,981 in 1930.

In one letter exchange between Howard and Lovecraft in late 1932, both touched on the differences between their environments as they related to their perception of the police. Howard, from small-town Texas, explained to Lovecraft,

In a certain town where I happened to be staying, an officer had trouble with a certain private citizen. ... The officer came up to him suddenly on the street one day and shot him down without a word. ... If you were as familiar with the working of Texas law as I am, you wouldn't even ask if the officer was acquitted. Of course he came clear. ... From what you say, this could not have happened in the East. But it DID happen in Texas. (p. 448)

Lovecraft, from a large city, then responds to this by writing,

Regarding the behavior of police in Texas-I must confess myself completely dumbfounded and bewildered by the array of data you bring up! No wonder our lifelong and instinctive reactions to law-enforcement have been antipodally different-for truly, I never dreamed of the existence of such conditions as your reports indicate! It sounds like a piece of sensational and extravagant fiction in this day and age. (p. 472)

He reiterated his astonishment at what Howard wrote by commenting later in the same letter, "In all my life, I never heard any such complaints against the police here" (p. 474).

\section{Police corruption}

The letter exchange between Howard and Lovecraft often focused on the general issue of police corruption. Howard mentioned multiple sources of the day for his assertion that police corruption was a problem.

As for the modern police system, I must confess that my admiration for it is not high. I hear much of its efficiency-and at the same time, in newspaper editorials, from the mouths of lecturers, speakers, reformers, and the pens of political and social writers, I hear that the nation is staggering with corruption and vice. ( $p$. 387) 
Howard ended this the portion of the letter with a summation of how he saw policing in the 1930s.

I can't believe that the police machine works universally with anything like a smooth tread. These remarks need not be taken to mean that I am an anarchist, a criminal-sympathizer, or a rabid cop-hater. But I do believe that the system as a whole is too corrupt. I have respect and admiration for any fearless, honest officer of the law. (p. 388)

Lovecraft replied to this by first making a counter-argument against Howard's sources, and then made a racist comment regarding what he believed was the extent of police corruption by writing the following:

Regarding police corruption-it is important for the observer to realise (1) that its effects on the general outward order of a city as encountered by the average respectable citizen are vastly less considerable than one would think from the speeches of reformers, and (2) that although simple graft is virtually universal, the famous close alliance betwixt gangs and police occur only in very large cities with extensive foreign (usually Italian) populations. (p. 416)

Lovecraft later reiterated his second point by arguing that police corruption was limited mainly to large metropolitan cities. As he explained to Howard,

It is in cities of the larger class-of a million or more population-that police corruption usually extends so far as to become a serious problem-though even there no respectable person is often in danger unless he is engaged in certain trades affected by racketeering. (p. 418)

In other words, police corruption really did not affect the common person, ergo, it was nothing to be concerned about.

Howard wrote back with a critical preface to his comments and wrote, "Let me say that I am sincerely glad that the police system in the East is as good as you say it is" (p. 448). He continued by commenting that what he was really saying was that "it is corruption and not the system itself that I object to" (p. 448). He also clarified that "the perfection of the Eastern police system does not mean that the system in all parts of the country is perfect" (p. 448). Later in the same letter, Howard made an additional point about his views of the problems of police corruption when he stated, "There are many fine men in Texas in ranks of the law; without them chaos and anarchy would result. But surely it is not fanaticism or outlawry to wish to eliminate the worst spots of 
corruption and injustice" (p. 449). Howard then drew his discussion of his beliefs to a conclusion when he explained to Lovecraft, "It isn't law-enforcement I resent, but the vandals that parade under the cloak of law" (p. 449).

The exchange on this topic continued over the course of their correspondence, often with each challenging the other about their sources, and both often straying into other topics. Much later in their letter exchange, Howard tried to sum up the differences between himself and Lovecraft on police corruption when he wrote the following:

The only difference in our views seems to be that I believe that corruption, brutality and crookedness among the police is more widespread than you seem to believe, considering the country as a whole, and not merely your section or mine. (p. 830)

Despite Lovecraft's erudite ways, he did appear to fall into the trap by believing that his personal experiences were the same as everyone else's.

\section{Police brutality}

The topic of police corruption often led into a debate on the issue of police brutality. Lovecraft initially raised the subject when he argued it was the lawlessness of the people that contributed to police brutality. He wrote, "If the citizens would outlaw violence as it is outlawed by the older Anglo-Saxon regions, there would be an infinitely better chance of improving the police" (p. 753). Howard challenged him on this notion by arguing that it was the exact opposite when he wrote the following:

You've got it backwards when you assume that the ruthlessness of the police is a result of the lawlessness of the common people. The common people are sometimes driven to desperation by the brutality of the police, who are merely carrying out instructions of corrupt officials, in turn doing the bidding of big business. (p. 776)

Still, Lovecraft returned to his previous argument by saying that police were not brutal against innocent citizens; they were ruthless when confronted with the criminals who deserved the brutality he countered. Lovecraft explained, "Even the cases of brutality sometimes reported usually have as their victims definite underworld characters whose real guilt in a thousand ways is enough to make them deserve all that they get and more" (p. 796). 
Journal of Qualitative Criminal Justice \& Criminology • 2020 | Volume Public Opinion of the Police in 1930s America: A Qualitative Historiographical

Lovecraft continued in this manner during several letters and even carried his argument as far as to suggest that Howard's issues with police brutality were nothing more than anti-police sentiment. Howard, clearly frustrated over Lovecraft's oversimplification of his views, replied,

As for the police, I can't understand why you repeatedly charge me with objecting to the necessary routine of keeping the peace, when all I have ever objected to was acts of unnecessary and wanton brutality; all I ever said was that these acts are more common than you seem to realize, and I say this, not because I'm such a Goddamned fool as to have an actual prejudice against the police, but simply because my studies of the matter, over a period of some six years, have convinced me that it is the truth. (p. 920)

\section{The third degree}

One other aspect of Howard and Lovecraft's exchange regarding police brutality was the discussion of police use of the third degree. This was a common slang term in the 1920s and 1930s for police use of brutality to gain a confession from a suspect. It was Howard who introduced this specific topic when he wrote in August of 1932, "I note that some indignation is being expressed over the country in regard to the detestable police practice of grilling prisoners" (p. 349). Lovecraft's response, at first, appeared to be in agreement with Howard when he wrote,

As for the "third degree" applied by police officers to prisoners-It indeed has come in vast amount of debating nowadays. Probably your position is right, for it certainly means peril to leave so much punitive latitude to minor officials with so little power of discrimination. (p. 368)

However, Lovecraft once again returned to the argument that only those deserving of this form of brutality deserved it. He commented, "And yet I can see the other side of the matter also ... such methods are reserved for known members of the toughest criminal class" (p. 368). Howard responded to Lovecraft's assertion by writing in the next letter, "I know the grilling methods of the police, for instance, are supposed to be applied only to the worst thugs. But I am hardly innocent enough to be fooled by that" (384).

\section{Romanticism of the police}

One aspect of the police debates between Lovecraft and Howard centered on Lovecraft's accusation that Howard was essentially a romanticist when it came to his 
beliefs about the police, especially when he evoked images of past policing and then compared it with modern policing. For instance, Howard wrote, "In the old days we had a type of law-officers as much superior to the present type as the old-time gunfighter was superior to the present type as the old-time gunfighter was superior to the present-day gang-rat" (p. 349). Howard talked of these old-style police officers as being "brave, honorable, and generally merciful when they had the edge" (p. 349), and how they "fought it out with the outlaws on more or less even terms" (p. 350). Lovecraft challenged Howard for these impracticable and unrealistic beliefs when he replied in this manner:

I think you take a somewhat impracticable-and essentially romantic rather than realistic - position when you call for "fair play" between the forces of order and those who have knowingly put themselves outside the pale by violating the social agreements on which civil action is based. (p. 369)

Lovecraft made the argument that the modern police did not exist to give criminals a fair chance or to be brave and chivalrous, but existed to deal effectively with the problems of crime and disorder. Lovecraft argued,

Remember that police are hired to produce certain results and perform certain defensive functions-not to make a parade of their personal chivalry and bravery. They must indeed be brave-for there are times when bravery is neededbut they must not try to test out that bravery when it is not necessary and when it might be the means of prolonging a social peril otherwise instantly conquerable. (p. 370)

Howard's reply to Lovecraft did not necessarily respond to Lovecraft's assertions when he wrote, "Romantic or not, I find much to admire in the old type of officer, who, instead of having everything on his side as does the modern cop, worked against every disadvantage and yet cleaned up his country" (p. 383). Howard also summarized his beliefs when he stated, "In the last analysis, law enforcement depended largely on the individual wearing the badge" (p. 383).

Lovecraft continued his argument in the next letter by making the point that "the business of a police man is to catch crooks, not to display bravery" and "officers are appointed to keep down crime and disorder-not to exploit their personality" (p. 412). He further argued that policing was not meant to be some "romantic fight" and he reiterated the point, this time with emphasis, when he stated: "For remember the basic 
Journal of Qualitative Criminal Justice \& Criminology • 2020 | Volume Public Opinion of the Police in 1930s America: A Qualitative Historiographical

truth-policemen are appointed to safeguard the community, not to play games of chivalry" (Lovecraft's italics, p. 413).

\section{Solutions}

As Howard and Lovecraft debated the problems of American policing, especially in relation to police corruption and brutality, Lovecraft brought up the need for finding policy solutions to the problems. He wrote, "Of course it is perfectly clear that no such conditions ought for a moment to be condoned-indeed, the only question is how to put a stop to the phenomenon and to the causes behind it" (p. 476). Lovecraft then addressed many of the problems the police face in modern society before concluding in the following way:

In the end, it is perhaps true that nothing but a gradual sociological evolution involving higher local standards of law, order, non-encroachment, and nonviolence will ever make the regulating machinery as free from cruelty, unevenness, and high-handedness as the corresponding machinery of long-settled regions. (p. 477)

Howard did not necessarily offer any particular policy solutions in return but discussed the reality that police officers faced violence on the job, and because of this, there would always be problems associated with it.

Lovecraft eventually focused his policy solutions on the problems of gun violence and the effect it had not just on society but on the police officers themselves when he explained,

What I am driving at is that the habit of regarding weapon fights lightly, and of using weapons on slight provocation, is bound to affect policemen's psychology in such a way that they will show an equally careless ruthlessness in their own actions. (p. 753).

Lovecraft then followed this declaration with his solution to the problem. "The only remedy is to build up a higher standard of human forbearance-to outlaw the free use of weapons and restore the Anglo-Saxon's original heritage of law, order, and rational adjustment" (p. 753). He argued that what was necessary was to continue developing civilization, because the more civilized a nation, the less prone to violence it becomes, which in turn, he believed, would remedy the problems of police corruption and brutality. Again, as he so succinctly believed, "If the citizens would outlaw violence as 
Journal of Qualitative Criminal Justice \& Criminology • 2020 | Volume Public Opinion of the Police in 1930s America: A Qualitative Historiographical

it is outlawed by the older Anglo-Saxon regions, there would be an infinitely better chance of improving the police" (p. 753).

\section{Discussion}

Lovecraft and Howard had been exchanging letters for approximately two years before they began discussing their opinion of American policing. Prior to that, they addressed the police in association with both crime and violence, but never offered opinions about the police themselves. In their first foray into this topic, Lovecraft wrote about how efficient the police would respond to a gunman in his hometown, while Howard wrote about American public opinion regarding the use of the third degree by the police. Lovecraft (the conservative) talked about what he thought the police were like, while Howard (the liberal) addressed the public's concern for the police and suggested that there was already somewhat of a divide in political speaking. This is in keeping with the predominant view of the literature that conservatives tend to be more supportive of police efficiency, while liberals tend to be suspicious of police power (Hindelang, 1974; Huang \& Vaughn, 1996; Zamble \& Annesley, 1987).

Turning to the two authors' personal contact with the police in their lifetime, neither had been arrested nor had much in the way of direct police contact, other than Howard's one encounter during a traffic stop in which he was a passenger. Howard was realistic in recognizing that not all officers were like the rude one who stopped him and his friends, as he said, "We did resent being treated like gangsters and thugs" (p. 505). Because Howard's perception of the police was lower than Lovecraft's, this may very well be in keeping with research findings-negative contact with the police reduces a person's perception of the police (Smith et al., 1991; Worrall, 1999). This also may explain why Lovecraft, having had no personal contact with the police, remained positive toward the police.

Out of the four variables that influence public opinion of the police, the neighborhood variable presents the starkest contrast between the two pulp fiction authors; Lovecraft was born in an urban environment and lived in one all his life, while Howard was born in small rural Texas, and also remained in that environment all his life. As the literature suggests, there were differences in perceptions of the police between the two authors (Apple \& O’Brien, 1983; Brown \& Benedict, 2002; Dunham \& Alpert, 1988; Reisig \& Parks, 2000). Howard (rural) had a more cautious regard for the police, while Lovecraft (urban) thought quite highly of them. This is in keeping with some of the literature regarding neighborhood differences (Janeksela et al., 1976; Zamble \& Annesley, 1987). 
Journal of Qualitative Criminal Justice \& Criminology • 2020 | Volume Public Opinion of the Police in 1930s America: A Qualitative Historiographical

The two key variables of personal contact and neighborhood not only appear to have shaped their opinions of the police, but the factors continued to shape their opinion of the police on specific topics such as police corruption, brutality, and the use of the third degree. Lovecraft considered the police to be professionals who did not engage in corrupt practices, the use of brutality, or use the third degree, except in very rare cases, which were, in his belief, both understandable and justifiable. Those rare cases of police misconducted included graft among a few large metropolitan police with "a million or more population" (p. 418), the use of brutal tactics against those "whose guilt in a thousand ways is enough to make them deserve all they get and more" ( $p$. 796), and the third degree, which was "reserved for known members of the toughest criminal class" (p. 368). Since he had no real contact with the police, lived in a large metropolitan city, and had a conservative ideology, Lovecraft viewed these problems with little to no concern for they were limited, in his mind, to the criminal class of only a few bad apples.

Howard, on the other hand, was much more cautious concerning his opinion of the police on the three topics (police corruption, brutality, and the use of the third degree) because he had slightly more contact with the police (at least one negative encounter), was from a rural environment, and had a liberal ideology. He demonstrated concern for the threat the police posed to civil liberties, not just for the criminals but also for the average citizen. Howard voiced his concern that "the system as a whole is too corrupt" (p. 388) and that "common people are sometimes driven to desperation by the brutality of the police" (p. 776). Regarding the police use of the third degree being limited to criminals, he told Lovecraft the following: "I am hardly innocent enough to be fooled by that" (p. 384). Howard's opinion of American policing shows recognition of a problem in American policing and demonstrated that these three issues have a wider impact on society and the people. Again, he fully demonstrated his concern for civil liberties over police practices.

Howard and Lovecraft raised two additional themes in their debates on the police. The first of these was Lovecraft's accusations that Howard was romanticizing the police, and, while no doubt at least partially true, Howard was also recalling what policing was like on the frontier and comparing it with modern policing, which he saw as not being more civilized than past policing because it was plagued with corruption and brutality. The other theme consisted of solutions for addressing the problems with the police. Howard remained largely silent on this topic, while Lovecraft took a shotgun approach and mentioned the civilizing process and gun control before offering a 
Journal of Qualitative Criminal Justice \& Criminology • 2020 | Volume Public Opinion of the Police in 1930s America: A Qualitative Historiographical

solution of returning to the "Anglo-Saxon's original heritage" of law and order, assuredly a romantic idea.

It should also be noted that the one confounding variable found in the literature, political ideology, may have been the variable that contributed in part or full to Howard and Lovecraft's differences in the opinion of the police (Huang \& Vaughn, 1996; Zamble \& Annesley, 1987). The conservative Lovecraft was highly supportive of the police, while the liberal Howard was far more critical and cautious in his support of the police. Political ideology, then, could have been more of a contributing factor than either personal contact or neighborhood.

\section{Conclusion}

The purpose of this research was to conduct a historiographical study using primary data to assess what public opinion of the police was like in the 1930s through a qualitative analysis of these historic letters. In recent times of crisis regarding the American police, the post-Ferguson era, individuals have the benefit of public opinion polls to assess the climate of police-citizen relations that had a part in the shaping of public opinion since the 1970s. There was an earlier crisis in police-public relations in the 1920s and 1930s arising out of Prohibition and the growth of organized crime that, historically speaking, was a time of unrest. However, until polling began, there was no way to assess the public opinion of crime in any definite, statistical manner.

Using the correspondence between two of the pulp era's greatest writers, Robert E. Howard and H. P. Lovecraft, allows the researcher to conduct the first such study to assess public opinion of the police in this time period. The primary data, in this case, the writers' correspondence, served as a rich data source because they wrote so widely on a range of topics and because, as writers, they conveyed their personal thoughts with clarity and style. Their differences with regard to two of the major influencing variables (personal contact with the police and neighborhood) and the one confounding variable (political ideology) also allowed for a qualitative assessment of their differences in public opinion of the police in accordance with the literature.

H. P. Lovecraft had little to no contact with the police, lived in an urban setting, had a conservative ideology, and demonstrated a higher opinion of the police. In contrast, Robert E. Howard had some contact with the police, lived in a rural environment, and had a liberal ideology; he showed a more cautious opinion of the police in the 1930s. Their viewpoints on such things as police corruption, brutality, and the use of the third degree were in keeping with findings from past literature on what generally shapes 
Journal of Qualitative Criminal Justice \& Criminology • 2020 | Volume Public Opinion of the Police in 1930s America: A Qualitative Historiographical

public opinion of the police. In light of this, the findings from this study lead to the conclusion that public opinion of the police and the factors that shape public opinion have changed little over the past 100 years.

\section{References}

Albrecht, S. L., \& Green, M. (1977). Attitudes toward the police and the larger attitude complex: Implications for police-community relationships. Criminology, 15(1), 67-86.

Apple, N. \& O’Brien, D. J. (1983). Neighborhood racial composition and residents' evaluation of police performance. Journal of Police Science and Administration, 11(4), 76-84.

Benson, P. R. (1981). Political alienation and public satisfaction with police services. Pacific Sociological Review, 24(1), 45-64.

Bentley, M. (1999). Modern historiography: An introduction. Routledge.

Berg, B. L. (2009). Qualitative research methods for the social sciences ( $7^{\text {th }}$ ed.). Allyn \& Bacon.

Berinksi, A. J. (2006). American public opinion in the 1930s and 1940s: The analysis of quota-controlled sample survey data. Public Opinion Quarterly, 70(4), 499-529.

Bridenball, B. \& Jesilow, P. (2008). What matters: The formation of attitudes toward the police. Police Quarterly, 11(2), 151-181.

Brown, B. \& Benedict, W.R. (2002). Perceptions of the police: Past findings, methodological issues, conceptual issues, and policy implications. Policing: An International Journal of Police Strategies \& Management, 25(3), 543-580.

Chandek, M. S. (1999). Race, expectations, and evaluations of police performance: An empirical assessment. Policing: An International Journal of Police Strategies \& Management, 22(4), 675-695.

Charmaz, K. (2008). Grounded theory as an emergent method. In S. N. Hesse-Biber \& P. Leavy, Eds.), Handbook of emergent methods (pp. 155-172). Guilford Press.

Charmaz, K. (2014). Constructing grounded theory. SAGE.

Charmaz, K., \& Belgrave, L. (2002). Qualitative interviewing and grounded theory analysis. In J. F. Gubrium, J. A. Holstein, A. B. Marvasti \& K. D. McKinney (Eds.), The 
Journal of Qualitative Criminal Justice \& Criminology • 2020 | Volume Public Opinion of the Police in 1930s America: A Qualitative Historiographical

SAGE handbook of interview research: The complexity of the craft (pp. 347-366). SAGE.

Cheurprakobkit, S. (2000). Police-citizen contact and police performance: Attitudinal differences between Hispanics and non-Hispanics. Journal of Criminal Justice, 28(4), 325-336.

Clark, J. P., \& Wenninger, E. P. (1964). The attitudes of juveniles toward the legal institution. Journal of Criminal Law, Criminology, and Police Science, 55(4), 482-489.

Converse, J. M. (2009). Survey research in the united states: Roots and emergence 1890-1960. Routledge.

Dean, D. (1980). Citizen ratings of the police: The difference contact makes. Law and Policy Quarterly, 2(4), 445-471.

Decker, S. H. (1981). Citizen attitudes toward the police: A review of past findings and suggestions for future policy. Journal of Police Science and Administration, 9, 80-87.

Decker, S. H. (1985). The police and the public: Perceptions and policy recommendations. In R. J. Homant \& D. B. Kennedy (Eds.), Police and law enforcement, 1975-1981 (pp. 89-105). AMS Press.

Dunham, R. G., \& Alpert, G. P. (1988). Neighborhood differences in attitudes toward policing: Evidence for a mixed-strategy model for policing in a multi-ethic setting. Journal of Criminal Law and Criminology, 75(2), 1276-1299.

Ekins, E. (2016). Policing in America: Understanding public attitudes toward the police. Results from a national survey. Cato Institute. https://www.cato.org/surveyreports/policing-america

Finn, M. (2013). Blood \& thunder: The life and art of Robert E. Howard. The Robert E. Howard Foundation Press.

Flanagan, T. J., \& Longmire, D. R. (1996). Americans view crime and justice: A national public opinion survey. SAGE.

Friedman, L. M. (1993). Crime and punishment in American history. Basic Books.

Gabbidon, S. L., \& Higgins, G. E. (2008). The role of race/ethnicity and race relations on public opinion related to the treatment of blacks by the police. Police Quarterly, 12(1), 102-115. 
Journal of Qualitative Criminal Justice \& Criminology • 2020 | Volume Public Opinion of the Police in 1930s America: A Qualitative Historiographical

Glaser, B., \& Strauss, A. (1967). The discovery of grounded theory: Strategies for qualitative research. Aldine.

Greene, A. C. (1999). The Santa Claus bank robbery. University of North Texas Press. Hillygus, D. S. (2011). The evolution of election polling in the United States. Public Opinion Quarterly, 75(5), 962-981.

Hindelang, M. J. (1974). Public opinion regarding crime, criminal justice, and related topics. Journal of Research in Crime and Delinquency, 11(2), 1010-116.

Hogan, J. M. (2009). George Gallup and the rhetoric of scientific democracy. Journal of Communication Monographs, 64(2), 161-179.

Huang, W., \& Vaughn, M. (1996). Support and confidence: Public attitudes toward the police. In T. J. Flanagan \& D. R. Longmire (Eds.), Americans view crime and justice: $A$ national public opinion survey (pp. 31-45). SAGE.

Iggers, G. G. (1997). Historiography in the twentieth century: From scientific objectivity to the postmodern challenge. University Press of New England.

Jacob, H. (1971). Black and White perceptions of justice in the city. Law and Society Review, 6(1), 69-89.

Janeksela, G. M., Deming, R. R., \& Nida, T. M. (1976). Attitudes toward the police. Police Law Quarterly, 5, 14-30.

Jayapalan, N. (2008). Historiography. Atlantic.

Joshi, S. T. (2010). Barbarism vs. civilization: Robert E. Howard and H. P. Lovecraft in their correspondence. In D. Schweitzer (Ed.), The Robert E. Howard reader (pp. 5181). Borgo Press.

Joshi, S. T. (2013). I am providence: The life and times of H. P. Lovecraft (Vol. 1-2). Hippocampus Press.

Joshi, S. T., \& Schultz, D. E. (Eds.). (2008). Essential solitude: The letters of $H$. P. Lovecraft and August Derleth, (Vol. 1-2). Hippocampus Press.

Joshi, S. T., Schultz, D. E., \& Burke, R. (Eds.). (2017). A Means to freedom: The letters of H. P. Lovecraft and Robert E. Howard (Vol. 1-2). Hippocampus Press. 
Journal of Qualitative Criminal Justice \& Criminology • 2020 | Volume Public Opinion of the Police in 1930s America: A Qualitative Historiographical

Leedy, P., \& Ormond, J. E. (2005). Practical research: Planning and design (8 ${ }^{\text {th }}$ edition). Prentice Hall.

Mayer, W. G. (1993). The changing American mind: How and why American public opinion changed between 1960 and 1988. The University of Michigan Press.

McDowell, W. H. (2002). Historical research: A guide for writers of dissertations, theses, articles, and books. Longman.

Milkovits, A. (2014, August 9). 150 years later, Providence police department's protective mission endures. Providence Journal.

Miller, J., \& Davis, R. C. (2008). Unpacking public attitudes to the police: Contrasting perceptions of misconduct with traditional measures of satisfaction. International Journal of Police Science \& management, 10(1), 9-22.

Momigliano, A. (1990). The classical foundations of modern historiography. University of California Press.

Moon, N. (1999). Opinion polls: History, theory and practice. Manchester University Press.

Page, B. I., \& Shapiro, R. Y. (1992). The rational public: Fifty years of trends in Americans' policy preferences. The University of Chicago Press.

Reisig, M. D., \& Chandek, M. S. (2001). The effects of expectancy disconfirmation on outcome satisfaction in police-citizen encounters. Policing: An International Journal of Police Strategies \& Management, 24(1), 87-99.

Reisig, M. D., \& Parks, R. B. (2000). Experience, quality of life, and neighborhood context: A hierarchical analysis of satisfaction with the police. Justice Quarterly, 17(3), 607-629.

Roehm, R. (Ed.). (2007). The collected letters of Robert E. Howard (Vol. 1-3). The Robert E. Howard Foundation Press.

Sampson, R. J., \& Jeglum-Bartusch, D. (1998). Legal cynicism and (subcultural?) tolerance of deviance: The neighborhood context of racial differences. Law and Society Review, 32, 777-804.

Scaglion, R., \& Condon, R. G. (1980). Determinants of attitudes toward city police. Criminology, 17, 485-494. 
Journal of Qualitative Criminal Justice \& Criminology • 2020 | Volume Public Opinion of the Police in 1930s America: A Qualitative Historiographical

Schultz, D. E., \& Joshi, S.T. (Eds.). (2017). Downward spire, lonely hill: The letters of $H$. P. Lovecraft and Clark Ashton Smith. Hippocampus Press.

Skogan, W. G. (1978). Citizen satisfaction with police services: Individual and contextual effects. Policy Studies Journal, 7(1), 469-479.

Smith, D. A., Graham, N., \& Adams, B. (1991). Minorities and the police: Attitudinal and behavioral questions. In M. J. Lynch \& E. B. Patterson (Eds.), Race and criminal justice (pp. 22-35). Harrow and Heston Publishers.

Smith, P. E., \& Hawkins, R. O. (1973). Victimization, types of citizen-police contacts and attitudes toward the police. Law and Society Review, 8(1), 135-152.

Smith, T. W. (1990). The first straw? A study of the origins of election polls. The Public Opinion Quarterly, 54(1), 21-36.

Stephens, J., \& Sinden, P.G. (2000). Victims' voices: Domestic assault victims' perceptions of police demeanor. Journal of Interpersonal Violence, 15, 534-547.

Strauss, A., \& Corbin, J. (1998). Basics of qualitative research techniques. SAGE.

Thomas, C. W., \& Hyman, J. M. (1977). Perceptions of crime, fear of victimization, and public perceptions of police performance. Journal of Police Science and Administration, 5(4), 305-317.

Walker, S. (1998). Popular justice: A history of American criminal justice (2 ${ }^{\text {nd }}$ edition). Oxford University Press.

Weitzer, R. (1999). Citizens' perceptions of police misconduct: Race and neighborhood context. Justice Quarterly, 16(4), 819-846.

Weitzer, R., \& Tuch, S. A. (1999). Race, class, and perceptions of discrimination by the police. Crime and Delinquency, 45(4), 494-507.

Worrall, J. L. (1999). Public perceptions of police efficacy and image: The "fuzziness" of support for the police. American Journal of Criminal Justice, 24, 47-66.

Zamble, E., \& Annesley, P. (1987). Some determinants of public attitudes toward the police. Journal of Police Science and Administration, 15, 285-290. 


\section{Contributor}

Willard M. Oliver is a professor of criminal justice at Sam Houston State University. He is the founding editor of the Journal of Qualitative Criminal Justice \& Criminology and his research interests include criminal justice policy, policing, and history. Author of the biography, August Vollmer: The Father of American Policing (Carolina Academic Press, 2017), Oliver is currently working on a biography of Texas author Robert E. Howard. 